\title{
Copying
}

Polar Record is registered with the Copyright Clearance Center, 222 Rosewood Drive, Danvers, MA 01923, USA. Organizations in the USA that are also registered with the CCC may copy material (beyond limits permitted by sections 107 and 108 of US copyright law) subject to payment to CCC of the per copy fee of $\$ 12.50$. This consent does not extend to multiple copies for promotional or commercial purposes. Code 0032-2474/99. Organizations authorized by the Copyright Licensing Agency may also copy material subject to the usual conditions. For all other use, permission should be sought from the Cambridge or the American Branch of Cambridge University Press (addresses below).

\section{Back Issues}

For vols 1-23 inclusive apply to The Editor, Polar Record, Scott Polar Research Institute, University of Cambridge, Lensfield Road, Cambridge CB2 1ER, UK. For vols 24 onward apply to Cambridge University Press, UK or USA.

\section{Advertising}

For details apply to the Editor or to the publishers.

\section{CAMBRIDGE UNIVERSITY PRESS}

Published by the Press Syndicate of the University of Cambridge

The Edinburgh Building, Cambridge CB2 2RU, United Kingdom

40 West 20th Street, Now York, NY 10011-4211, USA

10 Stamford Road, Oakleigh, Melboume 3166, Australia

Printed in the United Kingdom at the University Press, Cambridge. 


\section{POLAR RECORD}

VOLUME 35 NUMBER 195 OCTOBER 1999

\section{CONTENTS}

\section{ARTICLES}

Mystery cairns on Washington Irving Island. Karen McCullough and Peter Schledermann p 289

Identification and assessment of contaminated sites at Casey Station, Wilkes Land, Antarctica. Patrick P. Deprez, Michael Arens, and Helen Locher p 299

Reindeer herding and petroleum development on Poluostrov Yamal: sustainable or mutually incompatible uses? Bruce C. Forbes p 317

Colonisation of Greenland by plants and animals after the last ice age: a review. Ole Bennike p 323

Unlikely heroes: the story of the first men who stood at the North Pole. Christopher Pala p 337

\section{NOTES}

Pioneer measurements of sea-ice thickness in the Canadian Arctic 1850-1852. William Barr p 343

Springtime satellite view of the lower Yenisey region, Siberia. Olga Toutoubalina and Lawson W. Brigham p 344

Survey of recreational use, Yukon River, 1997. William Barr p 346

\section{REVIEWS}

This distant and unsurveyed country: a woman's winter at Baffin Island, 1857-58. W. Gillies Ross. Alex R. Buchan p 348

The photographs of HG Ponting. Beau Riffenburgh and Liz Cruwys. H.G.R. King p 349

General geocryology. E.D. Yershov. Colin E. Thorn p 350

Sinews of survival: the living legacy of Inuit clothing. Betty Kobayashi Issenman. Jill Oakes p 351

Albatross biology and conservation. Graham Robertson and Rosemary Gales (Editors). M. de L. Brooke p 351

Governing the frozen commons: the Antarctic regime and environmental protection. Christopher $\mathrm{C}$. Joyner. Peter J. Beck p 353

The Arctic sky: Inuit astronomy, star lore, and legend. John MacDonald. Carol Brice-Bennett p 354

Snow. Ruth Kirk. Peter Speak p 355

The circumpolar Inuit: health of a population in transition. Peter Bjerregaard and T. Kue Young. Julie Cruikshank p 355

Brief reviews p 357

OBITUARIES

Colonel Andrew Croft p 358

John Mayston Béchervaise p 359

Wing Commander Derek le Roy Bird p 360

CORRESPONDENCE

Shackleton at Stromness. Sir Gerald Elliot $p 362$

\section{SCAR BULLETIN No 135}

Stations of SCAR Nations operating in the Antarctic, Winter 1999 p 363

Summary Reports to XXV SCAR, Concepción, Chile, 27-31 July 1998 p 366

Address List of SCAR Executive Committee, Honorary Members, National Committees, Delegates, and Chief Officers p 377

Decisions, Resolutions, and Measures adopted at the XXIIIrd Antarctic Treaty Consultative Meeting, Lima, Peru, 24 May-4 June 1997 p 382

\section{CAMBRIDGE} UNIVERSITY PRESS

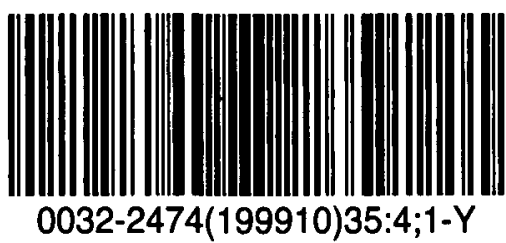

